\title{
The Need for Authentic Assessment for Speaking Skills at Junior High School
}

\author{
M. Zaim, Mukhaiyar, and Mentari Syahriati \\ English Language Education \\ Universitas Negeri Padang \\ Padang, Indonesia \\ mzaim_unp@yahoo.com, jmukhaiyar@yahoo.com, and misshope.105@gmail.com
}

\begin{abstract}
Authentic assessment is the process of gathering information from multiple and diverse sources in order to develop a deep understanding of what students know, understand, and can do with their knowledge and skill as a result of their educational experiences. Junior High School' teachers still have problems in using authentic assessment for assessing students' achievement. Therefore, appropriate model of authentic assessment should be developed and teachers' and students' need on authentic assessment should be analysed. This article aims to find out the students' and teachers' need on authentic assessment to assess speaking skills of junior high school students. This is a survey research and the data were collected through questionnaire from 40 students, interview 2 English teachers, and document analysis. The findings show that (1) the characteristics of authentic assessment needed by the teachers and students are simple and familiar with daily life, clear rubric score, communicative, and conducted continually; (2) there are four types of authentic assessment needed by students and teachers to assess speaking skills, they are brief question and answer, pair dialogue, oral report, and story retelling, and; (3) the text types of authentic assessment needed are monolog text, short functional text, functional text, transactional text, and interpersonal text.
\end{abstract}

Keywords - authentic assessment, speaking skill, need analysis, teaching English

\section{INTRODUCTION}

Assessment is a crusial part in the process of learning to determine whether the learning purposes have been achieved [1, 2, 3] and to provide information about the effectiveness of teaching methods used by the teachers (Moon, 2005). It is the systematic basis for making inferences about the learning and development of students. By doing assessment, teachers give students the opportunity to demonstrate their knowledges and skills [4]. It also provides the teachers with an opportunity to review their own teaching to enhance students' learning. Assessment is the process of defining, selecting, designing, collecting, analyzing, interpreting, and using information to increase students' learning and development.

Assessment has been implemented differently by different teachers. In some cases, assessment in language learning is focused on aspects of language, such as grammar and vocabulary so that most students master the language rather than fluent in communicating using the language [5]. Authentic assessment considers teaching, learning and assessment as an ongoing, interwined and all happening at the same time and that they strongly influence each other. Assessment should be closely related to teaching and learning, and authentic assessments are more widely accepted by students as opposed to standardized tests since authentic assessments become integral parts of the instructional cycle [6].

There are some problems in implementing authentic assessment at junior high school in Indonesia. In his study on the implementation of authentic assessment in junior high school in Indonesia, English teachers have difficulties in making a proper assessment rubric to assess the oral language skills [7]. Teachers need to develop a good and appropriate assessment rubric to assess students' speaking skill that provide high-quality information about the students' achievement. In addition, there are few opportunities to evaluate students' speaking skills at school because speaking assessment is not administered in any formal exams including the junior high school final exam. This was happened because English learning in junior high schools put a greater emphasis on reading comprehension in order to pass the national examination

The goals of learning English at junior high school in grade eight students are to develop the communication competence at the functional level, to understand English in global world, and to make the students understand and be able to develop the language skills for their daily life communication. While, the aim of learning speaking at English subject in junior high school is to develop the students' competence in oral communication [8]

The pre-liminary observation done by the researchers indicated that some English teachers still use traditional assessment instead of using authentic assessment in assessing speaking skill even though the assessment is the one recommended in the school based curriculum. Other teachers use authentic assessment, however they do not implement the whole characteristics of good authentic assessment. Moreover, the teachers also tend to use unclear scoring rubrics of 
speaking skills. The teachers do not tell to the students in what aspects of skills they will be assessed [2]. To help students to speak English well, teachers should assess their speaking skill by using authentic assessment. Students are asked to be creative, innovative and independence learner. In other words, students learn how to apply their skills to authentic tasks and project. Authentic assessment aims to assess student abilities in real world situation.

\section{Authentic Assessment}

Authentic assessments are considered to be performance-based tasks done in an environment that is actually closely approximates to the real world setting. Assessment is an ongoing process that encompasses a wide range of methodological techniques. Authentic assessment can be devised by the teachers or in collaboration with the students by engaging students' voice [9]. When applying authentic assessment to students learning and achievement, a teacher applies criteria related to construction of knowledge, disciplined inquiry, and the value of achievement beyond the school. Assessment is assessment that occurs continually in the context of a meaningful learning environment and reflects actual and worthwhile learning experiences that can be documented through observation, anecdotal records, journals, logs, work samples, conferences, portfolios, writing discussions, experiments, presentations, exhibits, projects and other methods [10]. In authentic assessment, the students use their knowledge effectively to solve the problem in their real life. In addition, authentic assessment is the process of evaluation which involves some activities [11]. The assessment should be realistic and relevant to the skills taught during the teaching-learning process in classroom activity. In short, it can be concluded that authentic assessment is the process of gathering information from multiple and diverse sources in order to develop a deep understanding of what students know, understand, and can do with their knowledge as a result of their educational experiences.

Some characteristics of authentic assessment, they are (1) authentic assessment requires some collaboration with others; (2) authentic assessment must be scored with reference to authentic standards of performance which students must understand to be inherent to successful performance; and (3) typical procedures of assessment design are reversed, and accountability serves students learning [12]. Moreover, authentic assessments (1) require students to perform, create, produce or do something, (2) use real world context or simulations, (3) are nonintrusive in that they extend the day to day classroom activity, (4) allow students to be assessed on what they normally do in class every day, (5) use task that represent meaningful instruction activities, (6) focus on process as well as product, (7) tap into higher-level thinking and problem solving skill, (8) provide information about strengths and weaknesses of students, (9) multiculturally sensitive when properly administered, (10) ensure that people, not machines, do the scoring, using human judgment, (11) encourage open disclosure of standards and rating criteria, and (12) call upon teachers to perform new instructional and assessment roles. So, it is clear that authentic assesssments should reflect the real world situation and require students to perform or do something.

There were some studies regarding the use of authentic assessment in language learning process in Indonesia. Authentic assessment in teaching and learning process is a form assessment that can increase the students' ability in speaking. Students' ability can be measured well with authentic assessment and teacher can assess the students' language ability and skills in learning precisely [13]. Most teachers do not understand and do not implement authentic assessment in language learning in the classroom [14]. Language teachers expect the guide books that contain the concept of authentic assessment to measure the language proficiency. Moreover, English teachers faced some difficulties in using authentic assessment for productive skills (speaking and writing) and they need the appropriate model of authentic assessment for assessing speaking and writing skills [7]. Furthermore, teachers still get problems in assessing certain language function and various forms of authentic assessment for speaking skill [3]. These studies reveal that models of authentic asessment for speaking skills are needed by English teachers in Junior High School in Indonesia.

In conclusion, authentic assessment evaluates students' ability to communicate with other and apply their knowledge and skills, not only the knowledge and skills they have acquired but also how they acquired them. Junior high school teachers still have problems in implementing authentic assessment although it has been a must to be implemented as required in current curriculum, the 2013 Curriculum.

\section{Need Analysis of Authentic Assessment}

Need analysis is considered to be a systematic process of gathering information about students' needs and preferences, interpreting the information, and making decision based on the interpretation in order to meet the need [15]. Needs analysis is a formal process that focuses on how a product addresses the needs of a human. Need analysis is a attemp to collect as much information as possible in order to build a comprehensive understanding of the needs and issues facing for an instruction. It is a procedure for collecting information about the need of a particular group of students. One of the activities involved in need analysis is gathering information for developing a curriculum [16]. Need analysis can be conducted by the teacher who wants to assess what students need to learn. In line with Brown and Abeywickrama, Need analysis can be directed at the goals and content of a course [17]. In addition, need analysis is an important part in designing the goals of a course that can identify the overall purposes of the course. From some definitions above, it can be concluded that need analysis is the process of gathering information from the students to achieve the curriculum goals. The outcomes of need analysis is used for designing a curriculum, learning materials and instruction.

Learning need is what the learner needs to do in order to learn. Target need is what the learner needs to do in the target situation. Then, they divide target need into three 
categories: necessities, lacks, and wants. Necessities are what the learner has to know in order to function effectively in target situation. Lacks are what the learner knows already and what he does not know. By knowing what the learner knows, we can decide which of necessities the learner lack. Wants are the target needs of the learner [18].

Related to the authentic assessment, an assessment designer should know what are the learning need and the target need of the learners. Therefore, need analysis should be made. Necessities in assessment are the demands of the target tasks that should be assigned by the learners such as level of vocabulary, level of grammar, level of content, and level of fluency. Lacks fit into present knowledge of what speaking aspects were not practiced in their previous learning [17].

An important thing of need analysis involves is looking at where students are at present. One way to investigate this is to look at assignments or task that the students did before. The quality of an assignment often depends on the conditions under which it was done. Other sources of information about lacks could come from the teacher who marks such assignment. Wants are aspects related to what the learners wish to learn. Students have their own views about what they think is useful for them. Information about wants is useful in working out whether the students' views and the need analyst's views are the same or not. If they are not the same, then the assessment designer may need to rethink the result of the need analysis or persuade the students that there is a more useful view of what they need.

Need analysis can be gathered by using questionnaire, interview, and group discussion [17, 15]. These instrument should be designed carefully so that they can be interpreted correctly to make decision. For designing an authentic assessment, need analysis is a very useful source of information to improve learners' speaking assessment. Learners' and teachers' necessities, lack, and want could be the basic information to design an appropriate assessment for speaking skills based on the curriculum requirement and what the learners want to be able to do regarding the speaking skills by the end of the English course.

This study will analyse students' and teachers' need on authentic assessment for speaking skill. This article discusses the need of authentic assessment related to characteristics of authentic assessment, types and topics of authentic assessments, and language function needed for assessing speaking skill.

\section{METHOD}

This study is a survey research. The data were collected through questionnaire, interview, and document analysis. The questionnaire was distributed to 40 students of Junior High School 3 Payakumbuh and the interview was conducted to 2 English teachers in the same school. The questionnaire was used to reveal the level of need of students related to the model of authentic assessment for speaking skill. Interview and document analysis were used to collect information from the teachers, the curriculum, the syllabus, and the lesson plan of the teachers related to the need of authentic assessment for speaking skills at grade eight Junior High School.

\section{RESULT AND FINDING}

The result and finding of the study are presented in accordance with two problems: students' need and teachers' need on authentic assesssment for speaking skill. In addition, document analysis was also done in order to find out the requirements of curriculum and its implementation in syllabus and lesson plan made by English teachers.

\section{A. Students' Need}

There are three components of students' need on authentic assessments for speaking skills of English at grade eight Junior High School: characteristics of authentic assessment, types of authentic assessment, and the ways to administer the authentic assessment.

\section{Characteristics of authentic assessment}

The first component of the need analysis is the characteristics of authentic assessment. There are four aspects in this component. The result of analysis can be seen in the table 1 .

Table 1. Characteristics of Authentic Assessment Needed

\begin{tabular}{|c|l|c|c|}
\hline No. & $\begin{array}{l}\text { Characteristics of Authentic } \\
\text { Assessment }\end{array}$ & Percentage & Category \\
\hline 1 & $\begin{array}{l}\text { The authentic assessment is } \\
\text { simple and familiar with the } \\
\text { students in daily life }\end{array}$ & $93.18 \%$ & High \\
\hline 2 & $\begin{array}{l}\text { Speaking assessment must be } \\
\text { communicative }\end{array}$ & $87.73 \%$ & High \\
\hline 3 & $\begin{array}{l}\text { Speaking assessment should } \\
\text { have a clear scoring rubric }\end{array}$ & $84.55 \%$ & High \\
\hline 4 & $\begin{array}{l}\text { Speaking assessment should } \\
\text { be conducted continuously }\end{array}$ & $83.18 \%$ & High \\
\hline
\end{tabular}

Note: L= Low: 26\%-50\%, M= Medium: 51\%-75\%, H= High: 76\%-100\%

The table above shows that the characteristics of authentic assessment highly needed by the students is the authentic assessment that is simple and familiar with the students in daily life (93.18\%). The students need authentic assessment that is useful for daily life, and it should be simple and familiar with students. The second highly needed of the characteristics of authentic assessment is communicative $(87.73 \%)$. The students need the authentic assessment that reflect the real communication. The third is speaking assessment should have a clear rubric (84.55\%). Scoring rubric should be easily understood by the students so that they can pay attention to the components of scoring rubric given. The last one is authentic assesssment should be applied continuously $(83.18 \%)$. The assessment for speaking must be conducted continuously during teaching and learning process.

The analysis above reveals that students need authentic assessment which is simple and familiar with their daily life, reflect the real communication, having clear scoring rubrics, and it should be conducted continuously.

\section{Types of authentic assessment}

There are four types of authentic assessment highly needed for speaking skill, they are pair dialogue, oral report, story of text retelling and brief question and answer. Here are 
the results of analysis with respect to each aspect in the table 2.

Table 2. Types of Authentic Assessment Needed

\begin{tabular}{|c|l|c|c|}
\hline No. & \multicolumn{1}{|c|}{$\begin{array}{c}\text { Types of Authentic } \\
\text { Assessment }\end{array}$} & Percentage & Categories \\
\hline 1 & Pair Dialogue & $92.27 \%$ & High \\
\hline 2 & Oral report & $87.73 \%$ & High \\
\hline 3 & Story of text retelling & $84.09 \%$ & High \\
\hline 4 & Brief Question and Answer & $80.91 \%$ & High \\
\hline 5 & Information Gap & $75.00 \%$ & Medium \\
\hline 6 & Role Play & $47.27 \%$ & Low \\
\hline
\end{tabular}

Note: L= Low: $26 \%-50 \%, \mathrm{M}=$ Medium: $51 \%-75 \%, \mathrm{H}=$ High: $76 \%-100 \%$

The table above shows that among the six types of authentic assessment, pair dialogue is highly needed by the students (92.27\%). Students are excited to do pair dialogue for speaking skills. After that, students want to do oral report $(87.73 \%)$. They like to report something related to the task given. The third type is story of text retelling (84.09\%). The fourth is brief question and answer $(80.91 \%)$. The next is information gap $(75.00 \%)$, that is categoried as medium. The last is role play, only $47.27 \%$ students need this type of assessment. Therefore, it is categoried as low.

The analysis above reveals that students' highly needed types of authentic assessments are pair dialogue, oral report, and story telling. Information gap and role play have the category of medium and low respectively.

\section{The Ways to Administer Authentic Assessment}

The ways to administer authentic assessment can be seen from four items: giving scoring criteria, being done in the classroom or out of the classroom, giving times for asking questions, and giving the model and example for the students. It can be seen from the table 3 .

Table 3. The Ways to Administer the Authentic Assessment

\begin{tabular}{|c|c|c|c|}
\hline No. & Assessment Process & Percentage & Categories \\
\hline 1 & $\begin{array}{l}\text { The teachers give scoring } \\
\text { criteria about speaking } \\
\text { assessment for the students }\end{array}$ & $89.09 \%$ & High \\
\hline 2 & $\begin{array}{l}\text { Assessing speaking is done } \\
\text { in the classroom and also } \\
\text { out of the classroom }\end{array}$ & $82.73 \%$ & High \\
\hline 3 & $\begin{array}{l}\text { The teachers give the } \\
\text { students time for asking } \\
\text { questions }\end{array}$ & $82.27 \%$ & High \\
\hline 4 & $\begin{array}{l}\text { The teachers do the } \\
\text { assessment by giving model } \\
\text { and example for the } \\
\text { students }\end{array}$ & $74.91 \%$ & Medium \\
\hline
\end{tabular}

Note: L= Low:26\%-50\%, M= Medium: 51\%-75\%, H= High: 76\%-100\%

The table above shows that among the four ways to administer the authentic assessment, the highly needed ways are the teachers give scoring criteria about speaking assessment $(89.09 \%)$, assessing speaking is done in the classsroom and outside the classroom $(82.73 \%)$, and teachers give students time for asking questions $(82.27 \%)$. While for giving a model and example for the students before doing the assessment only needed in category medium $(74.91 \%)$.

The analysis above reveals that students' highly needed among the four ways to administer the authentic assessments are having scoring rubrics, doing assessment in and outside the classroom, and giving students time to ask questions. Giving a model and example for the students before doing the assessment has the category of medium.

\section{B. Teachers' Needs}

The data of teachers' needs were collected through interview with 2 English teachers of Junior High School 3 Payakumbuh taught at grade eight. The interview focused on the teachers' need on the characteristics of authentic assessment, the types of authentic assessment for speaking skill, and the ways to administer the authentic assessment.

\section{Characteristics of authentic assessment}

The teachers needed authentic assessment for speaking which have the following characteristics: (1) simple, (2) tasks related to daily communication, (3) communicative, (4) having clear scoring rubrics, and (5) doing continuously. However those characteristics of good authentic assessment were not implemented well by the teachers to assess speaking skills, because the teachers gave the topics in the text book that was not related to their daily life.

\section{Types of Authentic Assessment}

There are 11 types of authentic assessments needed by the the teachers. The level of needed can be categorized as high, medium, and low. Look at the table 4.

Table 4. The Types of Authentic Assessment Needed by Teachers

\begin{tabular}{|c|l|c|c|}
\hline No & $\begin{array}{c}\text { Types of Authentic } \\
\text { Assessment }\end{array}$ & Percentage & Category \\
\hline 1 & Oral Interview & $88 \%$ & High \\
\hline 2 & Story of Text Retelling & $88 \%$ & High \\
\hline 3 & Pair Dialogue & $88 \%$ & High \\
\hline 4 & Oral Report & $88 \%$ & High \\
\hline 5 & Picture-Cued Description & $75 \%$ & Medium \\
\hline 6 & Information Gap & $75 \%$ & Medium \\
\hline 7 & Speech & $62 \%$ & Medium \\
\hline 8 & Discussion & $62 \%$ & Medium \\
\hline 9 & Role Play & $50 \%$ & Low \\
\hline 10 & Debates & $50 \%$ & Low \\
\hline 11 & Short Presentation & $50 \%$ & Low \\
\hline
\end{tabular}

Note: L= Low:26\%-50\%, M= Medium: 51\%-75\%, H= High: $76 \%-100 \%$

The table above shows that there are four types of authentic assessment needed in high category, they are oral interview, story of text retelling, pair dialogue, and oral report (80\%). Four types of authentic assessment are in medium category, they are picture-cued description, information gap (75\%), speech, and discussion (62\%). Three types of authentic assessment are in low category, they are role play, debates, and short presentation $(50 \%)$.

The analysis above reveals that students' highly needed types of authentic assessments are oral interview, story of text 
retelling, pair dialogue, and oral report. picture cued description, information gap, speech, and discussion have the category of medium. While role play, debates, and short presentation have the category of low.

\section{The Ways to Administer Authentic Assessment}

The teachers agree that the authentic assessment should be conducted during teaching and learning process because students need ongoing assessment, where they are assessed directly during the classroom activity. Teachers should assess the students' speaking skill by using analytical scoring rubric during teaching and learning process continuously to know the students' progress.

\section{Document Analysis}

Three documents were analysed to know the need of authentic assesssment for speaking at grade eight junior high school, they are curriculum, syllabus, and lesson plan. The documen analysis from English curriculum and syllabus reveals that there are four competence standards at grade eight of Junior High School, they are expressing meaning in oral texts, transactional and interpersonal, functional and a short monologue in the form of narrative and recount text of their daily life. The result of document analysis can be seen in the table 5 .

Table 5. Types of Text and Topics Needed for Speaking Skills

\begin{tabular}{|c|c|c|c|}
\hline No & Core Competence & Types of text & Topics Needed \\
\hline 1 & $\begin{array}{l}\text { Expressing } \\
\text { meaning in } \\
\text { conversation of } \\
\text { transactional and } \\
\text { interpersonal of } \\
\text { short dialogue or } \\
\text { simple to interact } \\
\text { with daily life }\end{array}$ & $\begin{array}{l}\text { Short Functional } \\
\text { Functional } \\
\text { Transactional } \\
\text { Interpersonal }\end{array}$ & $\begin{array}{l}\text { Shopping } \\
\text { Clothes } \\
\text { Recipe } \\
\text { Things } \\
\text { School } \\
\text { Classmate }\end{array}$ \\
\hline 2. & $\begin{array}{l}\text { Expressing } \\
\text { meaning in oral } \\
\text { functional text } \\
\text { and a short } \\
\text { monologue to } \\
\text { interact with } \\
\text { daily life }\end{array}$ & $\begin{array}{l}\text { Short Functional } \\
\text { Short Monolog }\end{array}$ & $\begin{array}{l}\text { Self } \\
\text { Family } \\
\text { Animal } \\
\text { Fruits } \\
\text { Flowers } \\
\text { Historical Place } \\
\text { Actor/Actress } \\
\end{array}$ \\
\hline 3. & $\begin{array}{l}\text { Expressing } \\
\text { meaning in } \\
\text { conversation of } \\
\text { transactional and } \\
\text { interpersonal } \\
\text { verbal interaction } \\
\text { with the } \\
\text { surrounding } \\
\text { environment for } \\
\text { the simple short }\end{array}$ & $\begin{array}{l}\text { Transactional } \\
\text { Interpersonal }\end{array}$ & $\begin{array}{l}\text { Advertisement, } \\
\text { Announcement }\end{array}$ \\
\hline
\end{tabular}

The table above shows that there are four types of texts needed for speaking skills, they are short functional text, transactional text, interpersonal text, and monologue. These four texts can be used in some topics such as self, family, school, classmate, shopping, advertisement, announcement, etc.
From document analysis of lesson plan used by teachers for teaching speaking at grade eight junior high school, it is found that there are 18 topics usually used by teachers. The frequency of usage among these topics can be seen in the table 6 .

Table 6. Topic Needed in Authentic Assessment

\begin{tabular}{|c|c|c|c|}
\hline No & Speaking Topics & Avarage & Categories \\
\hline 1 & Classmate & $90 \%$ & High \\
\hline 2 & Advertisement & $90 \%$ & High \\
\hline 3 & Self & $80 \%$ & High \\
\hline 4 & Animal & $80 \%$ & High \\
\hline 5 & Flowers & $80 \%$ & High \\
\hline 6 & Shopping & $70 \%$ & High \\
\hline 7 & Announcement & $80 \%$ & High \\
\hline 8 & Recipe & $80 \%$ & High \\
\hline 9 & Actor/Actress & $80 \%$ & High \\
\hline 10 & Animals & $80 \%$ & High \\
\hline 11 & Family & $70 \%$ & Medium \\
\hline 12 & School & $70 \%$ & Medium \\
\hline 13 & Things & $70 \%$ & Medium \\
\hline 14 & Clothes & $70 \%$ & Medium \\
\hline 15 & Famous people & $60 \%$ & Medium \\
\hline 16 & Tourist Resort & $50 \%$ & Low \\
\hline 17 & Historical Places & $40 \%$ & Low \\
\hline 18 & Fruits & $30 \%$ & Low \\
\hline
\end{tabular}

The table above shows that, in relation to the frequency of use of the topics in speaking class and the assessment activities, the frequency of using the topics are various. From the 18 topics, 10 topics are in high category (classmate, advertisement, self, animal, flowers, shopping, announcement, recipe, and actor/actress), 5 topics are in medium category (family, school, things, clothes, and famous people), and 3 topics are in low category (tourist resort, historical places, and fruit).

Based on the result of analysis above, students' and teachers' need on authentic assessment for speaking skill at grade eight Junior High School can be drawn in the table7.

Table 7. Students' and Teachers' Need on Authentic Assessment for Speaking

\begin{tabular}{|c|c|c|c|}
\hline $\begin{array}{c}\text { Characteristics of } \\
\text { Authentic } \\
\text { Assessments }\end{array}$ & $\begin{array}{c}\text { Types of } \\
\text { Authentic } \\
\text { Assessments }\end{array}$ & $\begin{array}{l}\text { Speaking } \\
\text { Topics }\end{array}$ & Types of Text \\
\hline $\begin{array}{l}\text { - Simple } \\
\text { - Familiar } \\
\text { - Daily life } \\
\text { - Communicative } \\
\text { - Clear scoring } \\
\text { rubrics } \\
\text { - Conducted } \\
\text { continuously }\end{array}$ & $\begin{array}{l}\text { - } \text { Brief } \\
\text { Question } \\
\text { and Answer } \\
\text { - Pair } \\
\text { Dialogues } \\
\text { - Oral report } \\
\text { - Story text } \\
\text { retelling }\end{array}$ & $\begin{array}{l}\text { - } \text { Self } \\
\text { - Family } \\
\text { - } \text { Things } \\
\text { - Places } \\
\text { - Person } \\
\text { - Report } \\
\text { - Short } \\
\text { - } \text { Famous } \\
\text { - } \text { people } \\
\text { - Shopping }\end{array}$ & $\begin{array}{ll}\text { - } & \text { Short } \\
& \text { Functional } \\
\text { - } & \text { Functional } \\
\text { - Transactional } \\
\text { - Interactional } \\
\text { - Monologue } \\
\text { - Descriptive } \\
\text { - Narrative } \\
\text { - Recount } \\
\text { - Report } \\
\text { - Procedures }\end{array}$ \\
\hline
\end{tabular}

The characteristics of authentic assessment needed by students and teachers are in line with Wiggin who said that 
authentic assessment occurs continually in meaningful learning environment. Brown \& Abeywickrama added that authentic assessments use real world context, encourage open disclosure of standards and rating criteria and allow students to be assessed in what they normally do in class every day. Moreover, O’Malley \& Pierce states that authentic assessment may develop a deep understanding of what students know, understand, and can do with their knowledge as a result of their educational experience $[12,9,11]$.

There are six types of authentic assessment needed for speaking skill at junior high school 3 Payakumbuh, they are brief question and answer, pair dialogues, oral report, and story text retelling. This is in line with Brown \& Abeywickrama who stated that authentic assessments require students to perform, create, produce, or do something. The four types of authentic assessment reflect this [9].

Speaking topics should be related to real world situation. The topics such as self, family, person, place, things, famous people, shopping are found in real world situation. There are three function of speaking, they are (1) talks as interaction, (2) talks as transaction, and (3) talks as performance. Talks as interaction refers to when the people meet, they exchange greetings, engage in small talk and to establish a comfortable zone of interaction with others [16]. Talks as transaction refers to situations where the focus is on what is said or done such as describing something, asking question, asking for clarification, conforming information, making suggestion and agreeing or disagreeing something. Talks as performance is usually in the form of monolog rather than dialogue such as giving a speech, and giving a sales presentation.

The English curriculum has decided the types of text to be used in learning English at Junior High School. There are four types of text that should be learned in Junior High School functional, transactional, interactional, and monologue [8]. There are also four kinds of text: descriptive, narrative, procedure, and recount. These types of text should be learned in all language skills (listening, speaking, reading, and writing).

\section{CONCLUSION}

Teachers' and students' need on authentic assessment for speaking skills were analyzed in order to develop the appropriate models of authentic assessment for speaking skills suitable for grade eight Junor High School. This research has found four needs of authentic assessment. They are related to characteristics of autentic assessment, types of authentic assessment, and the ways to administer authentic assessment. The characteristics of authentic assessment needed by the teachers and students are simple and familiar with daily life, clear rubric score, communicative, and conducted continually. The types of authentic assessment needed by students and teachers to assess speaking skills are brief question and answer, pair dialogue, oral report, and story retelling. The text types of authentic assessment needed are monolog text, short functional text, functional text, transactional text, and interpersonal text.

\section{Acknowledgment}

This article is written based on the developmental research on authentic assessment funded by Ministry of Research, Technology and Higher Education in 2017. The writers would like to express their sincere appreciation to the teachers and students as participants of this research.

\section{References}

[1] Angelo, T.A., \& Cross, K.P. (1993). Classroom Assessment Techniques: A Handbook for College Teachers. San Francisco: Jossey-Bass Publishers

[2] Wiggins, G. (2008). What are some types of Assessment? http://www/edutopia.org/assessment-guide-description. Retrieved on July 2016

[3] Zaim, M. \& Refnaldi. (2016). "Teachers' Need on Authentic Assessment for Speaking Skills", Proceeding International Seminar on Languages and Arts-5. Padang: FBS UNP Press

[4] Moon T.R. (2005). "Development of Authentic Assessments for the Middle School Classroom”, The Journal of Secondary Gifted Education. 16 (2/3) Winter/Spring.

[5] Irwana, E. (2006). Penerapan asesmen otentik dalam pembelajaran bahasa Indonesia; Studi Kasus di SMPN 1 Wlingi, Kecamatan Wlingi, Kabupaten Blitar. Skripsi. Fakultas Sastra, Universitas Negeri Malang

[6] Fook, C.Y., \& Sidhu, G.K. (2010). Authentic assessment and pedagogical strategies in higher education. Journal of Social Sciences, 6 (2), 153-161. http://dx.doi. org/10. 3844/jssp. 2010.153.161

[7] Zaim, M. (2013). “Asesmen Otentik: Implementasi dan Permasalahannya dalam Pembelajaran Bahasa Inggris di Sekolah Menengah". Proceeding International Seminar on Languages and Arts. Padang: FBS UNP Press.

[8] Depdikbud. (2013). Kurikulum 2013. Jakarta: Kementerian Pendidikan dan Kebudayaan

[9] Brown, H,D. \& Abeywickrama, P. (2010). Language Assessment Principles and Classroom Practices (Second Edition). New York: Pearson Education, Inc

[10] Wiggins, G. (1997). Practicing what we preach in designing authentic assessments. Educational Leadership, 54 (4), 18-25.

[11] O’Malley, J.M. \& Pierce, L.V. (1996). Authentic Assessment for English Language Learning: Practical Approaches for Teachers. New York: Addison-Wesley Publishing Company

[12] Wiggins, G. (1993). A True Test: Toward More Authentic and Equitable Assessment. Phi Delta Kappan

[13] Taufina. (2009). "Authentic Assessment dalam Pembelajaran Bahasa Indonesia di Kelas Rendah SD”. PEDAGOGI: Jurnal Ilmiah Ilmu Pendidikan. 9 (1), 113-120.

[14] Nurgiantoro, B. \& Suyata, P. (2009). "Pengembangan Model Asesmen Otentik dalam Pembelajaran Bahasa", Cakrawala Pendidikan, 28 (3), 224-237. 
[15] Graves, K. (2000). Designing Language Courses: A Guide for Teachers. Boston: Heinle

[16] Brown, G \& Yule, G. (1999). Teaching the Spoken Language $\left(2^{\text {nd }} e d\right)$. Melbourne: Cambridge University Press

[17] Nation, I.S.P. \& Macalister, J. (2009). Language Curriculum Design (2nd ed). Wellington: School of
Linguistics and Applied Language Studies, Victoria University of Wellington.

[18] Hutchinson, T \& Waters, A. (1987). English for Specific Purposes: A Learning Centered Approach. Cambridge: Cambridge University Press 